\title{
Birth Preparedness and Complication Readiness Plans among Antenatal Attendees at Primary Health Centre of District Jhansi, U.P, India
}

\author{
Shubhanshu Gupta *1, Rashmi Yadav 2, A.K.M alhotra ${ }^{3}$. \\ ${ }^{* 1,2}$ Post Graduate Department Of Community M edicine, M LBM C, Jhansi (UP), India. \\ ${ }^{3}$ Professor and Head- Department Of Community M edicine, M LBM C, Jhansi (UP), India.
}

\section{ABSTRACT}

Background: Birth preparedness \& complication readiness (BPACR) is a strategy that effectively plan birth and deals with emergencies.

Objectives: 1. To assess the status of BPACR among antenatal women, 2. To study the factors associated with BPACR, 3. To assess the level of male participation in the birth plan.

Materials and M ethods: A facility based cross sectional study was conducted from June 2015 to November 2015 among 527 antenatal women attending at primary health centre at Jhansi. No sampling was done. A pretested, semi- structured interview questionnaire was used which includes socio- demographic profile, knowledge about danger signs, identified a trained birth attendant, identified a health facility, arranged for transport, and saved money for emergency.

Statistical Analysis: Data were entered and analysed in Epi-info software. Descriptive statistics was used to describe the distribution of all variables. Multivariate logistic regression analysis was conducted to analyze factors that were independently associated with having a birth plan.

Results: Status of BPACR index in our study is low (46.2\%). Mean age was $21.8 \pm 4.4$ years, while that of husband is $27.2 \pm 6.6$ years. Awareness about early registration was low (47\%), majority of women (83\%) identified skilled attendant at birth for delivery.

Conclusion: As the level of awareness regarding BPACR is low. Individual women, families and communities need to be empowered to contribute positively to making pregnancy safer by making a birth plan.

Implication of study: To reduce the morbidity and mortality in pregnant women.

KEY WORDS: BPACR, primary health centre, danger signs, birth attendant.

Address for correspondence: Dr. Shubhanshu Gupta, Post graduate, department of community medicine, M LBM C, Jhansi (UP), India. M obile no.: +919999310142

E-Mail: guptashubhanshu1@gmail.com.

\begin{tabular}{|c|c|c|}
\hline \multicolumn{3}{|c|}{ Online Access and Article Informtaion } \\
\hline \multirow{2}{*}{$\begin{array}{c}\text { Quick Response code } \\
\text { Dol: } 10.16965 / \text { ijims.2016.112 }\end{array}$} & \multicolumn{2}{|c|}{$\begin{array}{l}\text { International Journal of Integrative Medical Sciences } \\
\qquad \text { www.imedsciences.com }\end{array}$} \\
\hline & $\begin{array}{l}\text { Received: 04-04-2016 } \\
\text { Reviewed: 05-04-2016 }\end{array}$ & $\begin{array}{l}\text { Accepted: 19-04-2016 } \\
\text { Published: 10-05-2016 }\end{array}$ \\
\hline Source of Funding: Self & \multicolumn{2}{|c|}{ Conflicts of interest: None } \\
\hline
\end{tabular}

\section{BACKGROUND}

The World Health Organization (WHO) estimates that 300 million women in the developing world suffer from short-term or long-term morbidities brought about by pregnancy and childbirth. Most of maternal deaths occur in the developing world [1]. With 167 maternal deaths per 100,000 live births, it remains a major public-health challenge in India (SRS-2013) [2]. Majority of maternal deaths mainly occur due to medical causes like within 24 hours post-partum or duringlabour, delivery causing delayed care 
seeking, numerous interrelated socio cultura Ifactors also causes delay and contribute to thesedeaths. Care-seeking is delayed because of the delay in (a) Identifying the complication, (b) Deciding to seek care, (c) Identifying and reaching a health facility, and (d) Receiving adequate and appropriate treatment at thehealth facility [3]. A key strategy that can reduce the number of deaths from such causes is making a birth plan that constitutes birth-preparedness and complication-readiness measures for pregnant women, their spouses and their families [4]. Birth-preparedness and complication- readiness is a comprehensive package aimed at promoting timely access to skilled maternal and neonatal services. This stems from the fact that every pregnant woman faces risk of sudden and unpredictable life threatening complications that could end in death or injury to herself or to her infant [5]. BPACR package includes: Registration of pregnancy, Knowledge of danger signs,Plan for where to give birth,Plan for a skilled birth attendant, Plan for transportation, a birth companion, andldentification of compatible blood donors in case ofemergency [3]. Male partner involvement is critical if improvement in maternal health and reduction of maternal morbidity and mortality is to be realized. Evidences from different studies [6] suggest that BPACR improves preventive behaviours, improves knowledge of mothers about danger-signs, and leads to improvement in care-seekingduring obstetric emergency. However, no dataare available on BPACR status of antenatal women in district Jhansi (U.P), India. Hence, this study was done with the objective to assess the status and factors associated with BPACR among pregnant women attending a primary health centre and male participation in the birth plan.

\section{MATERIALS AND METHODS}

A facility based cross sectional study was conducted from June 2015 to November 2015 at primary health centre in Chirgaon district Jhansi (UP). Chirgaon is the field area under department of community medicine of M.L.B. medical college, Jhansi. It provides primary healthcare services like immunization, antenatal care, family planning, and treatment of minor ailments to the community. A total of 527 pregnant women were serially included in the study who attended antenatal clinic of PHC. No sampling was done as it was intended to carry out the study for a period of 6 months (half year); hence allpregnant women who attended the antenatal clinic forthe first time during the study period were included. Using an intervieweradministered questionnaire, data was collected on i) Socio-demographic variables such as age, education level, marital status, employment status etc. Socio- economic status was calculated by modified B.G.Prasad classification ii) Birth preparedness details about antenatal care practices, preferred place of delivery, knowledge of danger signs during pregnancy, labour and puerperium, identification of place or personnel for delivery, and arrangement for money and transport iii) Data was also collectedon involvement of husbands on birth plan which was asked by women. BPACR index was calculated by a set of indicators. These indicators are expressed in percentage of women having specific characteristics. BPACR index has been developed by the Johns Hopkin Bloomberg School of Public Health [11]. BPACR index was calculated from the following indicators:

- Women who knew about $>8$ danger signs of pregnancy.

- Women who knew about financial assistance provided by government in Janani Suraksha Yojana (JSY).

- Women who knew about transportation provided by government in JSY.

- Women who availed Antenatal Care(ANC) in 1st trimester by skilled provider.

- Women who identified skilled birth attendant for delivery.

- Women who identified mode of transportation.

- Women who saved money to pay for expenses. BPACR index was calculated as Ólndicator/7.

The study was approved by institutional ethical review board and permission was taken by CM 0 of the PHC. After taking an informed consent, the women were interviewed.

Statistical Analysis: Collected data were 
consolidated on Excel sheets and further analysed in Epi-info software 7.1.3.0 version. Multivariate logistic-regression analysis was conducted to analyze factors that were independentlyassociated with having a birth plan.

\section{RESULTS}

Table 1: Socio-demographic profile of study participants $(n=527)$.

\begin{tabular}{|c|c|}
\hline Characteristics & Frequency (\%) \\
\hline *Age & $21.8 \pm 4.4$ \\
\hline *Gestational age & $38.1 \pm 3.4$ \\
\hline *Age of husband & $27.2 \pm 6.6$ \\
\hline Caste & \\
\hline General & $147(27.8)$ \\
\hline $\mathrm{OBC}$ & $109(20.6)$ \\
\hline $\mathrm{SC} / \mathrm{ST}$ & $271(51.4)$ \\
\hline Religion & \\
\hline Hindu & $433(82.1)$ \\
\hline Muslim & $77(14.6)$ \\
\hline Others & $17(3.3)$ \\
\hline Socio-economic status & 100 \\
\hline Till class III & $77(14.6)$ \\
\hline Class IV & 427 (81) \\
\hline Class V & $33(4.4)$ \\
\hline Type of family & \\
\hline Nuclear & $324(61.4)$ \\
\hline Joint & $203(38.6)$ \\
\hline Education level & \\
\hline Illiterate & $310(59)$ \\
\hline Primary & $197(37.3)$ \\
\hline secondary & $20(3.7)$ \\
\hline Marital status & \\
\hline Single & $14(2.7)$ \\
\hline Married & $513(97.3)$ \\
\hline $\begin{array}{l}\text { Education level of husband } \\
\text { Illiterate }\end{array}$ & $57(10.8)$ \\
\hline Primary & $227(43)$ \\
\hline Secondary & $175(33.2)$ \\
\hline Graduate & $68(13)$ \\
\hline Occupation of husband & \\
\hline Unemployed & $7(1.3)$ \\
\hline Unskilled & $197(37.3)$ \\
\hline Semi- skilled and skilled & $213(40.4)$ \\
\hline Clerical/ shop owner & $97(18.4)$ \\
\hline $\begin{array}{l}\text { Semi-professional and } \\
\text { professional }\end{array}$ & $13(2.6)$ \\
\hline
\end{tabular}

*=mean \pm standard deviation
Table 1 shows the socio-demographic profile of study participants, mean age of study participants was 21.8 years; gestational age was 38.1 years, while age of husband was 27.2 years. $51.4 \%$ belongs to SC/ST caste. Hinduism (82.1\%) was found to be most common religion. Among the SES, $81 \%$ of the study participants belong to CLASS IV followed by till CLASS III according to modified B.G.Prasad classification.M ost of them belong to nuclear family (61.4\%). 59\% of study participants were illiterate, which is quite high as compared to husband. $77 \%$ of husband were involved in unskilled or semi-skilled type of occupation.

Table 2: Role of husband in birth preparedness.

\begin{tabular}{|c|c|}
\hline Characteristics* & Frequency (\%) \\
\hline During birth plan & \\
\hline $\begin{array}{l}\text { Had health education } \\
\text { on pregnancy and } \\
\text { childbirth } \\
\text { comnlications } \\
\text { Plan the place of } \\
\text { delivery } \\
\text { Saved money in case of } \\
\text { complications } \\
\end{array}$ & $\begin{array}{c}43(8) \\
113(21.4)\end{array}$ \\
\hline During antenatal care & \multirow[b]{2}{*}{$\begin{array}{c}366(69.4) \\
37(7) \\
23(4.3)\end{array}$} \\
\hline $\begin{array}{l}\text { Accompanied her } \\
\text { Looked after children } \\
\text { at home, if any } \\
\text { Take care of household } \\
\text { work }\end{array}$ & \\
\hline $\begin{array}{l}\text { During labour and } \\
\text { hospital care }\end{array}$ & \multirow[b]{2}{*}{$\begin{array}{l}313(59.3) \\
271(51.4) \\
97(18.4)\end{array}$} \\
\hline $\begin{array}{l}\text { Provided transport } \\
\text { Accompany her to } \\
\text { labour room } \\
\text { Bought baby clothes } \\
\text { Got some family } \\
\text { member to take care } \\
\text { of home } \\
\text { Pay hospital bills }\end{array}$ & \\
\hline
\end{tabular}

*=multiple responses

Table 2 shows the role of husband in birth preparedness which has been divided in three charactersitics during birth plan, antenatal care and labour and hospital care. $21.4 \%$ saved money in case of complications. $69.4 \%$ of husbands accompanied their wives during antenatal care and $51.4 \%$ accompanied them to labour room.

Table 3 shows awareness among study participants regarding antenatal care and danger signals during pregnancy. $89 \%$ were 
Table 3: Awareness among study participants regarding antenatal care and danger signals during pregnancy, labour and puerperium $(n=527)$.

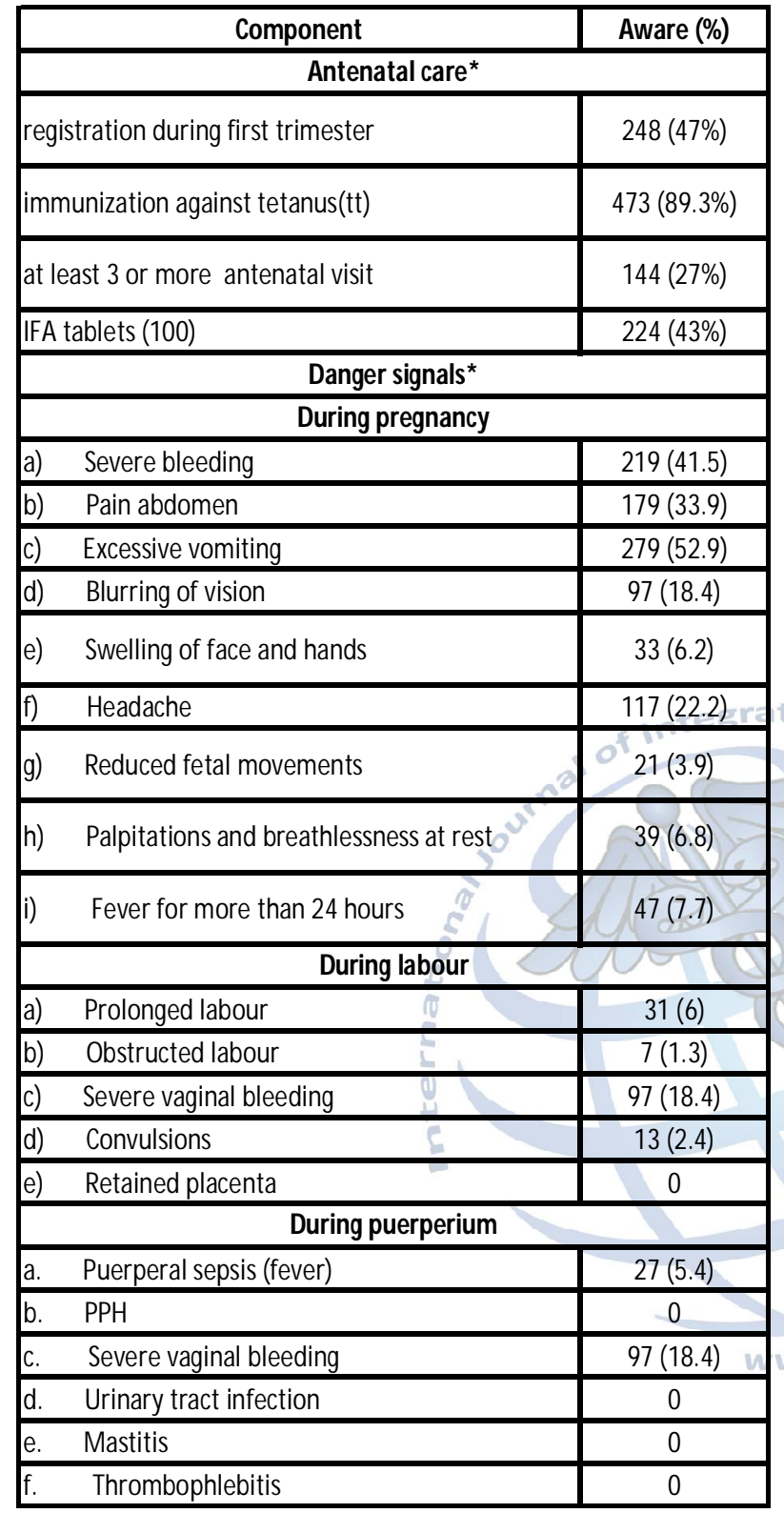

\section{$*=$ multiple responses}

aware towards immunization against tetanus while $47 \%$ were aware towards the importance of registration during first trimester. $43 \%$ were aware of IFA tablets. Vomiting and bleeding were found to be most common danger signals during pregnancy regarding awareness. Severe vaginal bleeding during labour and puerperium.

\section{BPACR index was calculated as Ólndicator/7, which was $46.4 \%$.}

Table 4 shows BPACR indicators among study participants. After all the seven indicators calculated with their respective percentages BPACR was $46.4 \%$.
Table 4: Status of birth preparedness and complication readiness among study participants $(n=527)$.

\begin{tabular}{|l|c|}
\hline \multicolumn{1}{|c|}{ Indicators } & (\%) \\
\hline $\begin{array}{l}\text { Women who knew about >8 danger signs } \\
\text { of pregnancy }\end{array}$ & $38 \%$ \\
\hline $\begin{array}{l}\text { Women who knew about financial } \\
\text { assistance provided by government in } \\
\text { Janani Suraksha Yojana (JSY) }\end{array}$ & $47 \%$ \\
\hline $\begin{array}{l}\text { Women who knew about transportation } \\
\text { provided by government in JSY }\end{array}$ & $27 \%$ \\
\hline $\begin{array}{l}\text { Women who availed Antenatal Care (ANC) } \\
\text { in 1st trimester by skilled provider }\end{array}$ & $44 \%$ \\
\hline $\begin{array}{l}\text { Women who identified skilled birth } \\
\text { attendant for delivery }\end{array}$ & $83 \%$ \\
\hline $\begin{array}{l}\text { Women who identified mode of } \\
\text { transportation }\end{array}$ & $41 \%$ \\
\hline $\begin{array}{l}\text { Women who saved money to pay for } \\
\text { expenses. }\end{array}$ & $45 \%$ \\
\hline
\end{tabular}

Table 5: Factors associated with BPACR among pregnant women attending a primary health centre on multi-variate logistic regression.

\begin{tabular}{|c|c|c|}
\hline Variables & Crude OR $(95 \% \mathrm{Cl})$ & Adjusted OR (95\% Cl) \\
\hline \multicolumn{3}{|c|}{ Age } \\
\hline 20 years & $.622(0.355-1.092)$ & - \\
\hline $20-24$ years & $.696(0.433-0.902)$ & - \\
\hline $25-29$ years & $.535(0.213-1.012)$ & - \\
\hline 30-34 years & 1 & 1 \\
\hline$>=35$ years & $.323(0.567-0.987)$ & - \\
\hline \multicolumn{3}{|c|}{ Religion } \\
\hline Hindu & $.414(0.674-1.191)$ & $.544(0.632-1.231)$ \\
\hline Muslim $e^{\circ}$ & $.113(0.213-0.768)$ & - \\
\hline Others & 1 & \\
\hline \multicolumn{3}{|c|}{ SES } \\
\hline Till class III & $.776(0.454-1.876)$ & $.444(0.576-1.087)$ \\
\hline Class IV & $1.67(1.878-4.12)$ & - \\
\hline Class V & 1 & 1 \\
\hline \multicolumn{3}{|l|}{ Education } \\
\hline Illiterate & 1 & - \\
\hline Primary & $.887(0.343-0.997)$ & 1 \\
\hline Secondary & $3.447(1.343-5.45)$ & - \\
\hline \multicolumn{3}{|c|}{ Education of husband } \\
\hline Illiterate & $.414(0.612-0.992)$ & $.212(0.345-0.765)$ \\
\hline Primary & 1 & - \\
\hline Secondary & $1.90(0.998-3.128)$ & - \\
\hline Graduate & $2.47(1.232-4.686)$ & - \\
\hline \multicolumn{3}{|c|}{ Antenatal care } \\
\hline $\begin{array}{l}\text { registration during first } \\
\text { trimester }\end{array}$ & $.112(0.556-0.875)$ & $.623(0.344-0.932)$ \\
\hline $\begin{array}{l}\text { immunization against } \\
\text { tetanus }(\mathrm{tt})\end{array}$ & $3.665(1.993-5.645)$ & - \\
\hline $\begin{array}{c}\text { at least } 3 \text { or more } \\
\text { antenatal visit }\end{array}$ & $.322(0.667-0.821)$ & - \\
\hline IFA tablets (100) & 1 & 1 \\
\hline
\end{tabular}


Table 5 shows the factors associated with BPACR among pregnant women attending PHC. The variables are independently associated with birth plan. Factors like age and religion shows no positive association with BPACR. While SES class IV shows a positive association. Secondary level of education of study participants shows a three times positive association with BPACR, similarly husbands who are educated to secondary or graduate level shows a positive association. Immunization against tetanus only shows a positive association among antenatal care.

Figure 1 shows the sources of knowledge regarding danger signs among the sources most of the study participants consider mother in law as the most important source of knowledge followed by doctors.

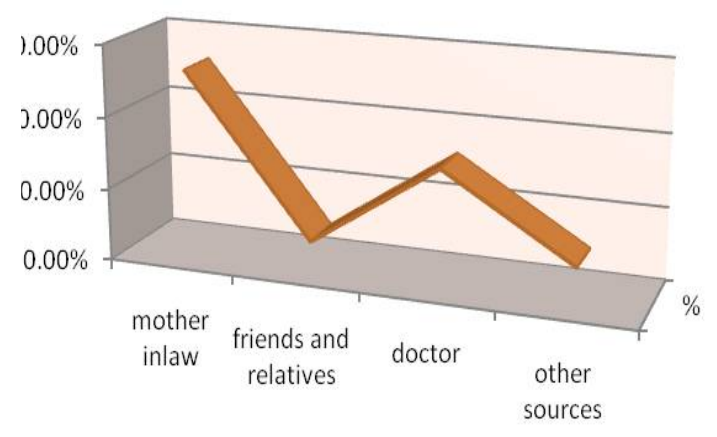

\section{DISCUSSION}

BPACR is a strategy to promote the timely use of skilled maternal and neonatal care, especially during childbirth, based on the theory that preparing for childbirth reduces delays in obtaining this care. Despite the great potential of BPACR in reducing the maternal and newborn deaths its status is not known. In our study, overall level of awareness regarding danger signs of pregnancy was very low (27.8\%), followed by poor awareness of danger signs of labor $(4.7 \%)$, were as only (4.4\%) women knew about danger signs during puerperium. Regarding the awareness during antenatal care $89.3 \%$ were aware towards immunization against tetanus, while $47 \%$ were aware about registration during $1^{\text {st }}$ trimester. $83 \%$ of women had identified a skilled attendant for birth which is similar to a multicentric study conducted in Nigeria [7], where it was reported that awareness of the concept of birth preparedness was high (70.6\%) but knowledge of specific danger signs was poor.In another study done in Nigeria [8], similar results regarding poor awareness of danger signs (28.3\%) were reported. A study conducted among pregnant and recently delivered mothers in Rewa district of Madhya Pradesh also highlighted similar findings where BPACR index was found to be $41 \%$ [9]. This study revealed poor level of knowledge about key danger signs and transportation services among mothers. Knowledge about financial assistance was high. The study showed that majority of the women had planned for skilled provider and transport but less than half (44.2\%) of the mothers planned for saving money which is nearly similar to our study results.

A field trial conducted in the neighboring country of Nepal [4] concluded that birth preparedness programs could positively influence knowledge and intermediate health outcomes, such as household practices and use of some health services. It was recommended that such programs can be implemented by government health services with minimal outside assistance but should be comprehensively integrated into the safe motherhood program rather than implemented as a separate intervention. In a study conducted in 11 slums of Indore [10], it was reported that less than half of the mothers $(47.8 \%)$ were well- prepared. Although awareness of the mothers about at least one danger-sign of pregnancy and delivery was not low, being $79.2 \%$ and $78.5 \%$, respectively; however, nearly three-fourths of the deliveries took place in the home. Overall, only $32 \%$ of the deliveries were attended by skilled birth attendants. In a study conducted in PHC of Delhi [11], the results are similar to our study where BPACR was $44 \%$, but in few aspects like awareness about danger signals, husbands role our study shown better results. Our study showed that SES class IV, education, husband's education and immunization against tetanus were associated with having a birth plan. Woman's education ( $P=0.001$ ) and her spouse's education ( $P=0.02)$ up to graduate and above were strong predictors of BPACR which is similar to a study done in rural Uganda where women's education and her spouse's education are significantly associated with BPACR [12]and a 
study done in Kenya [13] also reported women's education having positive influence on birth preparedness. The finding of low preference for the government health facilities during obstetric emergencies in the present study highlights the need for making efforts to improve the quality of care in the government facilities.

Due to better health information Educated women have better pregnancy outcome compared with uneducated women, are likely to make better choices, develop and implement a birth plan, and are more socially or financially empowered to make the necessary decisions in case of obstetric emergencies [14]. Our findings are in agreement with others [15] that many patients are admitted when they already have life threatening complications. This is a reflection of the quality of antenatal care at peripheral units, the quality of obstetric care at the referring units and the efficiency of the referral system. The finding that many of the referrals were in critical condition at admission suggests possible delays in making the decision to refer (possibly due to difficulty in diagnosis), delays in reaching the referral hospital or poor quality of care at the referring health facility. Indeed, diagnostic delays and misdiagnosis are responsible for many of the near-miss mortality and are common among emergency obstetric referrals $[16,17]$.

In our study, during antenatal care (69.4\%) of husband reported having been accompanied by spouses, while (11.3\%) looking after the home and children. During labour, (59.3\%) were accompanied by their spouses. Our findings are similar to those from a study in Northern Uganda [18] which found that husbands were actively involved in birth preparedness and complication readiness when their spouses were pregnant or in labour. In the Northern Uganda study, husbands those who were knowledgeable of ANC, learned health information from a health worker and whose spouses utilized skilled delivery services at last pregnancy were more likely to accompany their spouses at ANC. Some Observational studies suggest that including husbands in reproductive health interventions can enhance positive health outcomes. Where pregnant women and their male partners are given health education together, there is a greater net impact on maternal health behaviors compared to educating the women alone [19]. Women's ability to seek health care or implement lessons is often determined by the household head who usually is the husband who learned from health education interventions (by developing their own birth plans) [20].

\section{CONCLUSION}

As the level of awareness regarding BPACR is low i.e. $46.4 \%$. individual women, families and communities need to be empowered to contribute positively to make pregnancy safer. This can be done by raising awareness towards improving education for women.Antenatal care provides a golden opportunity to all the pregnant women to provide information, education and communication so that they along with their families can make the correct choices especially in event of any complications arising during delivery, childbirth or post-partum. This opportunity is missed many a times due to a number of reasons which should be addressed at the individual, family, community and the health provider's level.

\section{ACKNOWLEGEM ENT}

The authors are grateful to the study participants visiting the PHC for their valuable time and responses which help us to complete our study. Authors also give a big thanks to medical officer of PHC without his support it was difficult to conduct the study.

\section{REFERENCES}

[1]. WHO, UNICEF and UNFPA. (2007). Maternal M ortality in 2005: Estimates Developed by WHO, UNICEF, UNFPA. Geneva: WHO. Available from: http:// www.who.int/whosis/mme_2005.pdf [Last accessed on 2013 Oct 30].

[2]. SRS. Special Bulletin on M aternal M ortality in India 2009-11. (2013) Office of Registrar General of India. Available from: http:// www.censusindia.gov.in/ vital_statistics/SRS_Bulletins/FinalM M R \% 20 Bulletin-2007-09_070711.pdf [Last accessed on 2013 Oct 30].

[3]. M aternal and Neonatal Health Programme. (2004) Monitoring birth preparedness and complication readiness .Tools and indicators for maternal and newborn health. Baltimore: JHPIEGO. Available from: http://www.jhpiego.org/files/ BPACR toolkit.pdf [Last accessed on 2013 Nov 1]. 
[4]. RA M cPherson, N Khadka, JM Moore, M Sharma, Are birth-preparedness programmes effective? Results from a field trial in Siraha district, Nepal. Journal of Health Population and Nutrition. 2006;24(4):479-88.

[5]. JHPIEGO. Maternal and Neonatal health (M NH) Program, Birth preparedness and complication readiness. A matrix of shared responsibilities. Maternal and Neonatal Health. 2001;23-31.

[6]. M oran AC, Sangli G, Dineed R, Rawlins B, Yaméogo $M$, Baya B. Birth-preparedness for maternal health: findings from Koupéla district, Burkina Faso. J Health Pop Nutr2006;24:489-97.

[7]. Ekabua JE, Ekabua KJ, Odusolu P, Agan TU, Iklaki CU, Etokidem AJ. Awareness of birth preparedness and complication readiness in southeastern Nigeria. ISRN ObstetGynecol 2011.

[8]. Onayade AA, Akanbi OO, Okunola HA, Oyeniyi CF, Togun 00, Sule SS. Birth preparedness and emergency readiness plans of antenatal clinic attendees in Ile-Ife, Nigeria. Niger Postgrad M ed J 2010;17:30-9.

[9]. NIHFW, UNFPA, SS M edical College, Rewa. A study for assessing birth preparedness and complication readiness intervention in Rewa district of M adhya Pradesh. 2008-9. Available from: http:// nihfw.org/ pdf/RAHI-II\%20Reports/REWA.pdf [Last accessed on 2013 Oct 30].

[10]. Agarwal S, Sethi V, Srivastava K, Jha PK, Baqui A. Birth preparedness and complication readiness among slum women in Indore city, India. J Health PopulNutr 2010;28:383-91.

[11]. Acharya AS, Kaur R, Prasuna JG, Rasheed N. Making Pregnancy Safer-Birth Preparedness and Complication Readiness Study Among Antenatal Women Attendees of A Primary Health Center, Delhi. Indian J Community M ed 2015;40:127-34.

[12]. Kakaire O, Kaye DK, Osinde M O. M ale involvement in birth preparedness and complication readiness for emergency obstetric referrals in rural Uganda. Reprod Health 2011;8:12.
[13].M utiso SM , Qureshi Z, Kinuthia J. Birth preparedness among antenatal clients. East Afr Med J 2008;85:275-83.

[14]. Uganda Bureau of Statistics (UBOS) and ORCM acro, Uganda Demographic and Health Survey 2006. (Entebbe, Uganda and Calverton, Maryland, USA: Uganda Bureau of Statistics and ORC M acro, 2006)

[15]. A Adisasmita, PE Deviany, F Nandiaty, Stanton, Obstetric near miss and deaths in public and private hospitals in Indonesia. BMC Pregnancy Childbirth. 2008;8:10. doi:10.1186/1471-2393-810.

[16]. V Filippi, R Ganaba, RF Baggaley, T Marshall, KT Storeng, I Sombié., et al, Health of women after severe obstetric complications in Burkina Faso: a longitudinal study. Lancet. 2007;370(9595):13291337. doi:10.1016/S0140- 6736(07)61574-8

[17]. U Onwudiegwu, OC Ezechi, Emergency obstetric admissions: late referrals, misdiagnoses and consequences. Journal of Obstetric

[18]. R Tweheyo, J Konde-Lule, NM Tumwesigye, JN Sekandi, Male partner attendance of skilled antenatal care in peri-urban Gulu district, Northern Uganda. BMC Pregnancy and Childbirth. 2010;10:53. doi:10.1186/1471- 2393-10-53

[19]. BC M ullany, S Becker, MJ Hindin, The impact of including husbands in antenatal health education services on maternal health practices in urban Nepal: results from a randomized controlled trial urban Nepal: results from a randomized controlled trial. Health Education Research. 2007l;22(2):166176.

[20]. SSBloom, DWypij, GM Das, Dimensions of women's autonomy and the influence on maternal health care utilization in a north Indian city. Demography. 2001;38:67-78. doi:10.1353/dem.2001.0001.

\section{How to cite this article:}

Shubhanshu Gupta, Rashmi Yadav, A.K.Malhotra. Birth Preparedness and Complication Readiness Plans among Antenatal Attendees at Primary Health Centre of District Jhansi, U.P, India. Int J Intg Med Sci 2016;3(4):258-264. DOl: 10.16965/ijims.2016.112 